\title{
Effect of Tillage and Fertilizer Practices on Sorghum Production in Abergelle Area, Northern Ethiopia
}

\author{
Gebreyesus Brhane Tesfahunegn \\ Collegeof Agriculture,AksumUniversity, P. O. Box 287, Aksum, Ethiopia \\ (gebre042001@yahoo.com)
}

\begin{abstract}
Sorghum (Sorghum bicolor L. Moench) production is mainly constrained by soil water and nutrient deficits in northern Ethiopia. The aim of this research was to evaluate the effects of tillage and fertilizer practices on productivity of two sorghum varieties in Abergelle area, northern Ethiopia. The experimental design was split-plot design. The main-plot treatments included five tillage practices. These were shilshalo (traditional ridge without ties) for broadcasted planting (SBP), tied-ridging at planting (TROWAP), tied-ridging at four weeks after planting (TR4WAP), zero tillage (ZT), and shilshalo for row planting (SRP). Two fertilizer rates of nitrogen (N) and phosphorus (P), as0-0 N-P ha ${ }^{-1}$ (without fertilizer, F1) and 32-10 kg N-P ha ${ }^{-1}$ (with fertilizer, F2) treatments, were used in the sub-plots. The local sorghum varieties i.e., Woitoziraand Chibal (Sorghum bicolor L. Moench) were tested for two years (2002-2003). The pooled and yearly-basis data analysis showed that the main and interaction treatment effects were significantly $(\mathrm{P} \leq 0.05)$ influenced the yield and yield components of both varieties. This study also demonstrated sorghum yield incrementby 7 to $48 \%$ due to the interaction effect of TR0WAP with F2 as compared to the interaction effects of the other tillage treatments with F2. However, the increment of yield and yield components due to the tied-ridging and fertilizer interaction effects were higher for Chibalas compared to Woitozira. The mean sorghum crop yield due to TR0WAP interaction with F2 for Chibal was1.45 $\mathrm{t} \mathrm{ha}^{-1}$ and that of Woitozirawas $1.31 \mathrm{t} \mathrm{ha}^{-1}$. Thus, suitable time of tied-ridging integrated with proper rate of fertilizer should be adopted for effective increase of crop production in the semi-arid areas of northern Ethiopia such as the Abergelle area.
\end{abstract}

Key words: Abergelle area, Fertilizer, Sorghum varieties, Tied-ridging, Tillage practices, Northern Ethiopia

\section{INTRODUCTION}

About $41 \%$ of the Sub-Saharan Africa (SSA) farming land is in the semi-arid region. Only $2 \%$ of the arable lands are irrigated, which indicates that rain fed agriculture is the main source of crop production for the increasing populations in this region. However, rain-fed agriculture is not coping for unreliable rainfall and recurrent droughts that leads to subsequent production failures (Zougmoré et al., 2002). The effect of rainfall on soil erosion and the associated soil nutrient losses is expressed by the widespread of poor soil fertility and crust prone soils of cultivated land (Breman et al., 2001). In such environmental condition, sorghum (Sorghum bicolor L. Moench) is a major food crop in Ethiopia with approximately 297,000 ha production area per annum and 
in northern Ethiopia it accounted for 255,000 ha $\mathrm{y}^{-1}$ (Wortmann et al., 2006).Sorghum is one of the leading traditional food crops in Ethiopia comprising 15-20\% of the total cereal production in the country. It is the second major cereal crop next to teff (Eragrostis tef) in consumption and cultivable area and sorghum accounted for about $14.5 \%$ of the total cultivated area in the Tigray region (CSA, 2000; Wortmann et al., 2006).However, its average yield per unit area is not more than $1.0 \mathrm{t} \mathrm{ha}^{-1}$ (CSA, 2000), which is below the world average of $2.3 \mathrm{t} \mathrm{ha}^{-1}$ (Benti, 1993). Though sorghum yield is constrained by different factors, it is the dominant crop in the semi-arid areas such as the Abergelle area in the Tigray region, northern Ethiopia.

Two major factors that characterize agriculture in Ethiopia include (i) The erratic climatic conditions with frequent periods of water shortage (Stroosnijder and Van Rheenen, 2001; Tewodros Mesfin et al., 2009) and (ii) The presence of large areas of low fertile and crust prone soils (Morin, 1993; Breman et al., 2001). This situation is particularly worsened by continuous cultivation with low or no input application, overgrazing and trampling by cattle (Mando, 1997). The effects of these factors have resulted in severe human-induced land degradation (Sanchez et al., 1997; Wortmann and Ssali, 2001; Pendek et al., 2004), which is the major cause for crop production failure to meet the demand of population growth (Davidson et al., 2003).

Several studies have been conducted to understand soil degradation processes in Ethiopia (Holden and Shiferaw, 2002; Sonneveld, 2002). Among the soil degradation processes, nutrient depletion, surface sealing/crusting and soil erosion are the most prominent ones (Morin, 1993; Holden and Shiferaw, 2002). In order to limit further degradation and the associated production losses, assessing the impact of potential agronomic practices such as tillage and fertilizer practices on crop production is thus too crucial.

The formation of soil surface crusts increases runoff, which leads to severe water and soil loss. As a result, in the semi-arid areas of Ethiopia the main constraint to crop production is inadequate soil water and nutrient supply. However, this is not due to rain shortage but due to its poor distribution and losses as runoff (Grimay G/Samuelet al., 2009; Araya Alemie and Stroosnijder, 2010).For low soil infiltration and high rainfall intensity, runoff is responsible for severe soil and the associated nutrients losses even in flat and gentle slopes (Morin, 1993; Breman et al., 2001). Thus, to improve water use efficiency for crop production, increasing rainwater infiltration into the rooted soil zone is needed in order to be used through the processes of transpiration for biomass production. Because, limited water and nutrients interaction can 
limit crop growth; so there is a need to be tackled in synergy while improving crop yields in the situation of northern Ethiopia.

Integrated soil and crop management practices should be addressed simultaneously in order to reduce runoff and soil erosion associated nutrient losses, increase water infiltration, and nutrient availability for crop production (Breman et al., 2001). Micro-basins created by tillage can reduce runoff and increase infiltration and thereby water available for crop production (Gebreyesus Brhane et al., 2006; Gebreyesus Brhane Tesfahunegn and Wortmann, 2008). Tied-ridging is a form of micro-basin tillage which consists of ridging the soil typically to heights of 0.20 to 0.30 $\mathrm{m}$ and is blocked with earth ties spaced considering slope of the land, soil water infiltration rate, and expected intensity of rainfall. Planting of crop scan be either in the furrow or on the ridge based on the expected soil moisture required for a particular crop (Gebreyesus Brhane et al., 2006; Gebreyesus Brhane Tesfahunegn and Wortmann,2008; Tewodros Mesfin et al., 2009). The beneficial effects of tillage such as tied-ridging on crop yield vary due to differences in amount and distribution of rainfall, soil type, slope, landscape position, crop type, time of ridging, and the condition where rainfall events to result in significant runoff (Gebreyesus Brhane et al., 2006). Tied-ridging increased sorghum grain yield and soil water by more than 40 and $25 \%$, respectively, as compared to the traditional tillage practice (shilshalo) in northern Ethiopia (Gebreyesus Brhane et al., 2006). Studies also showed that lack of greater response to applied $\mathrm{N}$ and $\mathrm{P}$ fertilizer in Ethiopia was probably due to soil water deficit which is the major yieldlimiting factor (e.g., Tewodros Mesfin et al., 2009).According to Tewodros Mesfin et al. (2009), "profitable crop response to applied nutrients depends on soil water availability". However, improper use of tied-ridging can result in problems such as ridge over-topping, ridge failure, water logging, and total loss of the crop in severe storms (Jones and Clark, 1987; Gebreyesus Brhane et al., 2006).

Despite the above facts, however, so far, there has been insufficient published works that evaluate the role of tied-ridging and other tillage practices as part of moisture harvesting technique integrated with fertilizer at farmers' fields using different local varieties of sorghum in Ethiopia. Thus, the aim of this research was designed to evaluate the effect of tillage practices and inorganic fertilizer concurrently on the productivity of two sorghum varieties at farmers' field in the Abergelle area of Tigray region, northern Ethiopia. 


\section{MATERIALS AND METHODS}

\subsection{Study site}

This study was conducted at Abergelle sub-district (N13 $\left.144^{\prime} 27^{\prime \prime}, \mathrm{E} 38^{\circ} 58^{\prime} 50^{\prime \prime}\right)$ which is an administrative unit of Tigray region, northern Ethiopia (Fig. 1). The average elevation of the trial sites was about $1512 \mathrm{~m}$ above sea level. The slope of the sites ranged from 0.03 to $0.04 \mathrm{~mm}^{-}$ ${ }^{1}$.Annual rainfall had a uni-modal pattern and ranged between 400 and $700 \mathrm{~mm}$, with about $70 \%$ of the rainfall normally falling in July and August. Mean monthly temperature during the crop season was about $23^{\circ} \mathrm{C}$. The soil at the experimental sites was dominantly Vertic properties (Typic Pellustert), of low soil fertility (Gebreyesus Brhane et al., 2006).

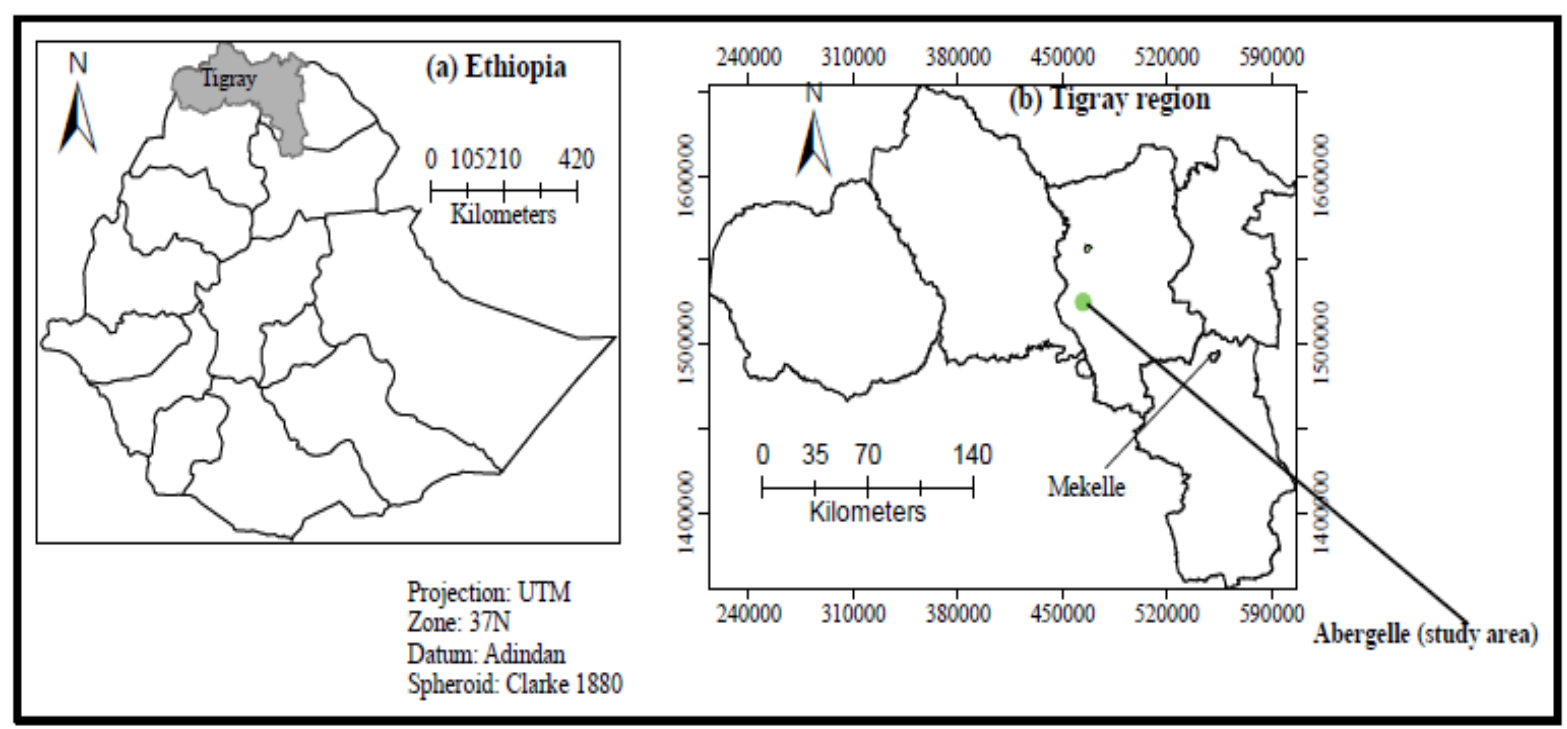

Figure 1.Map of the study area (A) Ethiopia, and (B) Tigray region with point indicator for Abergelle study site.

Sorghum mono-cropping is the common farming practice in the cropping system of the study area. This is because of its drought tolerance as compared to the other crops, which usually fail due to soil moisture stresses. However, farmers sometimes practice crop rotation if the farmland response to sorghum productivity is decreasing or totally failed. Abergelle was selected as research site for this study because this area is one of the most drought prone areas and also represents for the major sorghum growing areas in the region.

\subsection{Experimental Design and Treatments}

The experiment was conducted in 2002 and 2003crop seasons, using spilt-plot design experimental arrangement. The tillage treatments on the main-plot were shilshalo (traditional ridge without ties) for broadcasted planting (SBP); tied-ridging at planting (TR0WAP); tie- 
ridging at four weeks after planting (TR4WAP); zerotillage (ZT); and shilshalo furrow planting (SRP). Shilshalo is a traditional ridging without ties used for moisture harvesting and weed control using the traditional oxen-drawn plow known as maresha. Shilshalo was used by the farmers commonly four weeks after planting and forms ridges about $0.15 \mathrm{~m}$ in height and narrow furrows which are not tied. But the height of the ridges of tied-ridging was reached about $0.30 \mathrm{~m}$ and also has furrows wider than that of shilshalo by at least 0.05-0.10 m. Oxen-drawn ridging implement was used to construct ridges of $0.30 \mathrm{~m}$ height.

The two fertilizer levels on the sub-plot were 0-0 kg N-P ha ${ }^{-1}$ (without fertilizer, F1), and 32-10

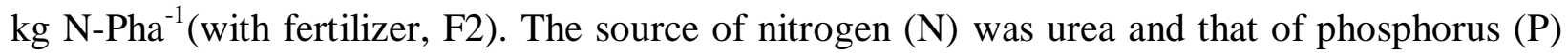
was diammonium phosphate (DAP) fertilizers as 50-50 kg urea-DAP ha ${ }^{-1}$. The F1 treatment was included because many farmers rarely applied fertilizer on sorghum crop. On the other hand, the inclusion of $\mathrm{F} 2$ was based on the fertilizer rate suggested as an extension package for moisture stressed areas such as the study site. The row planter was used to facilitate sorghum seeds planting in a row. Planting was done with oxen-drawn row planter in rows for all the main-plot treatments, except for SBP which was broadcasted manually by hand. The desired plant spacing of $20 \mathrm{~cm}$ was obtained by hand thinning at 21 days after sowing for sorghum plants planted in a row.

The experiment had three replications in 2002, and four replications in 2003. A farmer was considered as a block on this research as this was carried out on different farmers' fields. So, the three farmers were considered the same as three blocks. The uniformity of each plot in each block in terms of soil fertility was taken into consideration, and also management practices were kept to be similar throughout all the blocks and years of the experiments. Each tillage treatment was applied on the main-plot size of $20 \mathrm{~m}$ lengths $\mathrm{x} 9 \mathrm{~m}$ widths whereas the fertilizer treatments on the sub-plot size of $20 \mathrm{~m}$ lengths $\mathrm{x} 4.25 \mathrm{~m}$ widths. In both trial years, two local varieties of Sorghum bicolor L. Moench, namely, 'Woitozira' (early plated but late matured) and 'Chibal' (late planted but early matured) were used as test crops. The spaces between blocks, main-plots and sub-plots were 2.0, 1.0 and $0.5 \mathrm{~m}$, respectively. The distances between rows, tied-ridges, and ties were $0.75,0.75$ and $2 \mathrm{~m}$, respectively.

The cultural practices (weeding, plowing) of the experiment were the same as the farmers' practices in the area. No chemical was used for pest and weed control. The entire experimental area was tilled once using the traditional oxen-drawn maresha plow before imposing any of the 
treatments except for ZT, with no plow. All plots were weeded manually once during the cropping season. Planting was done in the furrow for all plots with tied-ridging at planting time. DAP was applied at planting in a band whereas urea was side dressed at 4 weeks after planting. The dates of tillage, planting and harvesting activities with respect to each sorghum local varieties are presented in table 1.

Table 1. Date of agronomic activities with regard to the local sorghum varieties experiment in 2002 and 2003 crop seasons (Note: WAP = Weeks After Planting).

\begin{tabular}{|llll|}
\hline Variety & Activities & 2002 & 2003 \\
\hline \multirow{5}{*}{ Woitozira } & Tie-ridging at planting & 22 June & 24 June \\
\cline { 2 - 4 } & Tie-ridging at 4 WAP & 18 July & 20 July \\
\cline { 2 - 4 } & Shilshalo & 18 July & 20 July \\
\cline { 2 - 4 } & Planting time & 22 June & 24 June \\
\cline { 2 - 4 } & Harvesting time & 6 November & 9 November \\
\hline \multirow{5}{*}{ Chibal } & Tie-ridging at planting & 18 July & 17 July \\
\cline { 2 - 4 } & Tie-ridging at 4 WAP & 17 August & 16 August \\
\cline { 2 - 4 } & Shilshalo & 17 August & 16 August \\
\cline { 2 - 4 } & Planting time & 18 July & 17 July \\
\cline { 2 - 4 } & Harvesting time & 27 October & 5November \\
\hline
\end{tabular}

\subsection{Data Collection Procedures and Statistical Analysis}

Data were collected on plant height, plant stand count (plant population), panicle length, grain yield, stover yield and 1000-seed weight. Rainfall data for the study durations were also collected. Randomly chosen five plants per row, which were assumed representative for the plot excluding boarder plants was taken to determine plant height just at harvesting time. Plant height was recorded in each of the central three rows by measuring the height from the ground to the tip of the panicle. Similarly,10 randomly selected plants in the plot were measured to determine panicle length per plant just at harvesting time. The plant stand count was also determined just at harvesting time by counting all stems and tillers in the harvested area. Seed weight was determined for sample of 1000 air-dried seeds at $125 \mathrm{~g} \mathrm{~kg}^{-1}$ moisture content. Above ground biomass yield (straw + yield) was determined by weighing after cutting the plants just at the surface of the soil and after air-drying. Grain yield was expressed at $125 \mathrm{~g} \mathrm{~kg}^{-1}$ moisture content. Pooled data analysis using the two years (2002 and 2003) data was carried out; besides to the 
yearly-basis analysis, with the help of MSTATC soft ware (Freed, 1994). Treatment differences were separated using least significant difference (LSD) at $\mathrm{P} \leq 0.05$.

\section{RESULTS}

\subsection{Tillage and Fertilizer Interaction Effect on 'Woitozira' Sorghum variety}

The data analyzed for plant height, panicle length, plant stand count, 1000 seed weight, grain yield, and stover yield of Woitozira (early planted but late matured) local sorghum variety using the pooled data from the two years (2002 and 2003) were significantly influenced $(\mathrm{P} \leq 0.05)$ by fertilizer and tillage interaction effects(Table 2). However, the yearly-basis analysis indicated that grain yield, seed weight, plant height, plant population (stand count) and panicle length were non-significantly $(\mathrm{P}>0.05)$ influenced by the tillage treatments in the absence of fertilizer for Woitozira variety in 2002 (data not shown).

In this study, the pooled and yearly-basis agronomic data analysis showed significant differences among most tillage treatments interacted with $\mathrm{F} 2$. The tallest sorghum plant height $(1.60 \mathrm{~m})$ was observed for TR0WAP interaction with F2 followed by TR4WAP with F2 (1.56 m). However, the shortest plant height was recorded from the interaction effect of ZT with F1 $(1.04 \mathrm{~m})$ followed by ZT with F2 $(1.21 \mathrm{~m})$ for Woitozira variety. Plant height found from the traditional ridging (shilshalo) (SBP) was taller than that of ZT but shorter than the other tied-ridging tillage treatments with both F1 and F2. A similar trend was observed for the treatment interaction effects on Woitozira sorghum variety data analyzed on yearly-basis, even though agronomic data performance was better in2003 than 2002 (data not shown).

The tillage treatment that showed the longest panicle length for Woitozira variety was TR0WAP $(236 \mathrm{~mm})$, followed by TR4WAP $(229 \mathrm{~mm})$ and the shortest was due to ZT $(191 \mathrm{~mm})$ in the presence of F2. The interaction effect of tillage treatments with F1 also showed similar trend, that is, the longest panicle length was due to TROWAP $(224 \mathrm{~mm})$ and the shortest was in ZT $(187 \mathrm{~mm})$. Generally, tillage without fertilizer (F1) had shorter panicle length than with fertilizer (F2) (Table 2). The lowest plant stand count, panicle length and 1000-seed weight as an average of both years (2002 and 2003) were recorded by the interaction effect of ZT followed by SBP with F2 and F1. But these parameters were performed better due to TR0WAP followed byTR4WAP with both F2 and F1 (Table 2). The performance of these and other crop growth 
traits were generally superior inTROWAP as compared to TR4WAP and the other tillage treatments interaction with both fertilizer rates.

Table 2. Mean of agronomic parameters for Woitozira (early planted but late matured) variety due to tillage and fertilizer interaction effects from two experimental seasons (20022003).

\begin{tabular}{|c|c|c|c|c|c|c|c|c|c|c|c|c|}
\hline \multirow[b]{2}{*}{ Treatment } & \multicolumn{2}{|c|}{$G Y, t h a^{-I}$} & \multicolumn{2}{|c|}{$S t, t h a^{-1}$} & \multicolumn{2}{|c|}{ S. wt, gm } & \multicolumn{2}{|c|}{$P H, m$} & \multicolumn{2}{|c|}{$P L, m m$} & \multicolumn{2}{|c|}{$S C 60 m^{-2}$} \\
\hline & $F 1$ & $F 2$ & $F 1$ & $F 2$ & $F 1$ & $F 2$ & $F 1$ & $F 2$ & $F 1$ & $F 2$ & $F 1$ & $F 2$ \\
\hline SBP & 0.72 & 0.95 & 3.4 & 4.7 & 19.5 & 24.5 & 1.27 & 1.38 & 202 & 213 & 268 & 423 \\
\hline TROWAP & 0.96 & 1.31 & 5.7 & 7.3 & 26 & 31.5 & 1.47 & 1.60 & 224 & 236 & 330 & 494 \\
\hline TR4WAP & 0.92 & 1.22 & 5.3 & 6.6 & 24.5 & 29 & 1.35 & 1.56 & 219 & 229 & 267 & 475 \\
\hline $\mathrm{ZT}$ & 0.50 & 0.98 & 2.2 & 4 & 14.5 & 17.5 & 1.04 & 1.21 & 187 & 191 & 258 & 383 \\
\hline SRP & 0.76 & 1.15 & 3.8 & 5.3 & 20.5 & 26.5 & 1.31 & 1.49 & 200 & 206 & 260 & 435 \\
\hline LSD 0.05 & 0.22 & 0.29 & 2.0 & 1.7 & 5.75 & 5.4 & 0.19 & 0.175 & 13 & 18 & 35 & 43 \\
\hline
\end{tabular}

Note: LSD, least significant difference at probability level $(\mathrm{P}) \leq 0.05$; SBP, traditional tillageshilshalo with broadcasted planting; TR0WAP, tie-ridging at planting; TR4WAP, tieridging at four weeks after planting; ZT, zero tillage; and SRP, shilshalo with row planting; F1, 0-0 kg N-P ha ${ }^{-1}$; F2, 32-10kg N-P ha' ${ }^{-1}$ GY, grain yield; st, stover yield; S. wt, 1000 seed weight; SC, plant stand count just at harvesting; PH, plant height; PL, panicle length.

The treatment interaction effect of TR0WAP with fertilizer (F2) showed the highest grain yield for Woitozira variety. For instance, TR0WAP with F1 gave grain yield of $0.96 \mathrm{t} \mathrm{ha}^{-1}$ whereas with F2 was about 1.31t ha $\mathrm{h}^{-1}$. The other tillage practices with F1 and F2 had yields below these values. The lowest yield was recorded from zero tillage (ZT) with F1 followed by F2, for about 0.5 and $0.98 \mathrm{t} \mathrm{ha}^{-1}$, respectively (Table 2). This table also shows that TROWAP followed by TR4WAP had a better treatment interaction effect on stover yield. The highest stover yield (7.3 t $\mathrm{ha}^{-1}$ ) was due to the interaction effect of TROWAP with F2 followed by $6.6 \mathrm{t} \mathrm{ha}^{-1}$ due to TR4WAP with F2. Conversely, the lowest stover yield of $2.2 \mathrm{t} \mathrm{ha}^{-1}$ was observed from the interaction effect of ZT with F1. The trend of tillage and fertilizer interaction effects on sorghum yields were similar for both F2 and F1, but yields were higher with F2 than that of F1 (Table 2).

\subsection{Tillage and Fertilizer Interaction Effect on 'Chibal' Sorghum variety}

The data on plant height, panicle length, 1000 seed weight, grain yield, and stover yield for Chibal (late planted but early matured) local sorghum variety tested using the pooled data from the two years (2002 and 2003) were significantly influenced $(P \leq 0.05)$ due to fertilizer and tillage interaction effects (Table 3).Similarly, the yearly-basis agronomic data analysis result for 
chibal variety showed a significantly different response to the main and interaction effects of the treatments (data not reported).

Table 3.Mean of agronomic parameters for Chibal (late planted but early matured)variety due to tillage and fertilizer interaction effectsfrom two experimentalseasons (2002-2003).

\begin{tabular}{|c|c|c|c|c|c|c|c|c|c|c|}
\hline \multirow[b]{2}{*}{ Treatment } & \multicolumn{2}{|c|}{$G Y, t h a^{-1}$} & \multicolumn{2}{|c|}{$S t, t h a^{-1}$} & \multicolumn{2}{|c|}{ S. wt, gm } & \multicolumn{2}{|c|}{$P H, m$} & \multicolumn{2}{|c|}{$P L, m m$} \\
\hline & $F 1$ & $F 2$ & $F 1$ & $F 2$ & $F 1$ & $F 2$ & $F 1$ & $F 2$ & $F 1$ & $F 2$ \\
\hline SBP & 0.84 & 0.96 & 5.10 & 6.05 & 28 & 34 & 1.91 & 2.10 & 268 & 274 \\
\hline TR0WAP & 1.05 & 1.45 & 7.30 & 8.9 & 35 & 41 & 2.13 & 2.37 & 281 & 298 \\
\hline TR4WAP & 0.95 & 1.24 & 6.55 & 8.2 & 34 & 39 & 1.99 & 2.29 & 283 & 296 \\
\hline $\mathrm{ZT}$ & 0.55 & 0.73 & 3.65 & 4.65 & 20 & 25 & 1.58 & 1.75 & 239 & 243 \\
\hline SRP & 0.85 & 1.02 & 5.35 & 6.55 & 31 & 35 & 1.88 & 2.17 & 269 & 276 \\
\hline LSD 0.05 & 0.18 & 0.20 & 1.71 & 1.56 & 2.0 & 2.3 & 0.25 & 0.19 & 13 & 25 \\
\hline
\end{tabular}

Note: LSD, least significant difference at probability level $(\mathrm{P}) \leq 0.05$; SBP, traditional tillageshilshalo with broadcastedplanting; TR0WAP, tie-ridging at planting; TR4WAP, tieridging at four weeks after planting; ZT, zero tillage; and SRP, shilshalo with row planting; F1, 0-0 kg N-P ha ${ }^{-1}$; F2, 32-10kgN-P ha ${ }^{-1}$; GY, grain yield; st, stover yield; S. wt, 1000 seed weight; SC,PH, plant height; PL, panicle length.

The pooled analysis data showed that the tallest plant height $(2.37 \mathrm{~m})$ was found from the treatment interaction effect of TR0WAP with F2. This was followed by the interaction effect of TR4WAP with F2, which was about $2.29 \mathrm{~m}$. A similar trend was observed on these tillage practices with F1even though the tallest plant height was measured with F2 (Table 3). In a similar manner, the longest plant panicle length was recorded for tillage interaction effects with F2. Among such treatments, TR0WAP showed the longest panicle length $(298 \mathrm{~mm})$ whereas the shortest panicle length was with ZT $(239 \mathrm{~mm})$. The highest 1000 seed weight was also for TR0WAP interaction with F2 (41 gm) followed by TR4WAP with F2 (39 gm). The lowest 100 seed weight for Chibal sorghum variety was recorded from ZT interaction effect with both F1 (20 gm) and F2 (25 gm) (Table 3).

Grain and stover yield of Chibalsorghum variety were the highest due to interaction effects of TR0WAP with F2.Generally, better sorghum yields were observed when moisture harvesting tillage practices integrated with fertilizer (Table 3). For example, sorghum grain yield from interaction effect of TR0WAP with F2 was the highest $\left(1.45 \mathrm{t} \mathrm{ha}^{-1}\right)$ whereas with F1 was $1.05 \mathrm{t}$ $\mathrm{ha}^{-1}$ for Chibal variety. The highest stover yield for F2 with TR0WAP was 8.90t ha ${ }^{-1}$. Conversely, the lowest grain yield $\left(0.55 \mathrm{t} \mathrm{ha}^{-1}\right)$ and stover yield $\left(3.65 \mathrm{t} \mathrm{ha}^{-1}\right)$ were obtained due to ZT interaction effect with F1. This was followed by the traditional ridging (shilshalo) interaction (C) CNCS, Mekelle University 
with both F1 and F2 which showed poor yield performance But yield was higher with F2 as compared to F1 (Table 3). In general, there was no statistical difference in grain and stover yield among ZT, SBP and SRP interaction effect with F1. The interaction effects among SRP, SBP and TR4WAP with F1 on grain and stover yields were also non-significantly different. But among these tillage practices, their interaction effect with F2 showed a significantly different in grain and stover yields(Table 3).

\subsection{Tillage and Fertilizer Separate Effect on Yield of Local Sorghum varieties}

The tillage main treatments were influenced significantly $(\mathrm{P} \leq 0.05)$ the grain and stover yields that pooled from the two crop seasons for both local varieties tested in this study (Table 4). The yearly-basis data showed that sorghum yields of both varieties were higher in 2003 than in 2002. But the yields of Chibal variety showed generally higher than the Woitozira variety in 2003 (data not reported). The tillage main treatment effect showed a higher yield due to TR0WAP, followed by TR4WAPthan SRP. The lowest yield from the tillage effect was found as a result of ZT followed by SBP for both Woitozira and Chibalsorghum varieties (Table 4). The mean yield of the two varieties due to the tillage main treatment effect also showed a significantly different. The highest mean yields of the two varieties were obtained due to TROWAP followed by TR4WAP, but the lowest was due to ZT (Table 4). Such trends of the main plot (tillage) treatment effects were consistent with the tillage and fertilizer interaction results. Generally, the effects of tillage treatments indicate that the grain and stover yields were higher for Chibal than Woitozira sorghum variety. The tillage main treatment effects increased grain yield by 5-10\% and up to $28 \%$ for stover yield of Chibal as compared to its effect on Woitozira variety.

In addition, Table 4 shows a significant different $(\mathrm{P} \leq 0.05)$ in sorghum yields between the effects of fertilizer rates within and between varieties as a mean of the two crop seasons data. The mean grain yield was $1.03 \mathrm{tha}^{-1}$ for $\mathrm{F} 2$ and $0.78 \mathrm{t} \mathrm{ha}^{-1}$ for $\mathrm{F} 1$ for the early planted but late matured variety (Woitozira). Similarly, the grain yield due to F2 was $1.10 \mathrm{t} \mathrm{ha}^{-1}$ and by F1 was $0.85 \mathrm{t} \mathrm{ha}^{-1}$, for the late planted but early matured variety (Chibal). The mean sorghum grain yield of the two varieties from the two years was 1.07 and $0.82 \mathrm{t} \mathrm{ha}^{-1}$ for F2 and F1, respectively. The stover yields also showed a similar trend with that of grain yield of both varieties with regard to F1 and F2 (Table 4). The stover yield was 4.1 and $5.59 \mathrm{t} \mathrm{ha}^{-1}$ due to F1 for Woitozira and Chibal, respectively. On the other hand, stover yield was 5.60 and $6.87 \mathrm{t} \mathrm{ha}^{-1}$ due to $\mathrm{F} 2$, for Woitozira and Chibal, respectively. In general, there was a significant difference between the effects of 
fertilizer treatments on mean grain and stover yields of the two varieties across the two years (Table 4).

Table 4.Mean of the effect of tillage (main effect) and fertilizer (sub-plot) treatment effects on grain and stover yields of two sorghum varieties using two experimental seasons (2002 and 2003).

\begin{tabular}{|lllllll|}
\hline & \multicolumn{2}{c}{ Variety: Woitozira } & \multicolumn{2}{c|}{ Variety: Chibal } & \multicolumn{2}{c|}{ Mean acrossvarieties } \\
\cline { 2 - 7 } Treatment & \multicolumn{2}{c}{ Yield, t ha ${ }^{-1}$} & \multicolumn{2}{c|}{ Yield $\boldsymbol{h a}^{-1}$} & \multicolumn{2}{c|}{ Yield $^{-1}$} \\
\cline { 2 - 7 } & Grain & Stover & Grain & Stover & Grain & Stover \\
\hline Tillage & & & & & & \\
\hline SBP & 0.84 & 4.1 & 0.90 & 5.6 & 0.87 & 4.9 \\
\hline TR0WAP & 1.14 & 6.6 & 1.20 & 8.3 & 1.17 & 7.5 \\
\hline TR4WAP & 1.08 & 6.0 & 1.12 & 7.4 & 1.10 & 6.7 \\
\hline ZT & 0.58 & 3.2 & 0.65 & 4.2 & 0.62 & 3.7 \\
\hline SRP & 0.88 & 4.7 & 0.94 & 6.0 & 0.91 & 5.4 \\
\hline LSD 0.05 & 0.25 & 2.03 & 0.20 & 1.64 & 0.23 & 1.84 \\
\hline Fertilizer & & & & & & \\
\hline F1 & 0.78 & 4.1 & 0.85 & 5.59 & 0.82 & 4.8 \\
\hline F2 & 1.03 & 5.6 & 1.10 & 6.87 & 1.07 & 6.2 \\
\hline LSD 0.05 & 0.22 & 0.87 & 0.20 & 0.99 & 0.21 & 1.30 \\
\hline
\end{tabular}

Note: SBP, traditional tillage-shilshalo with broadcasted planting; TR0WAP, tie-ridging at planting; TR4WAP, tie-ridging at four weeks after planting; ZT, zero tillage; and SRP, shilshalo with row planting; F1, 0-0 kg N-P ha- ${ }^{-1}$ F2, 32-10kg N-P ha ${ }^{-1}$.

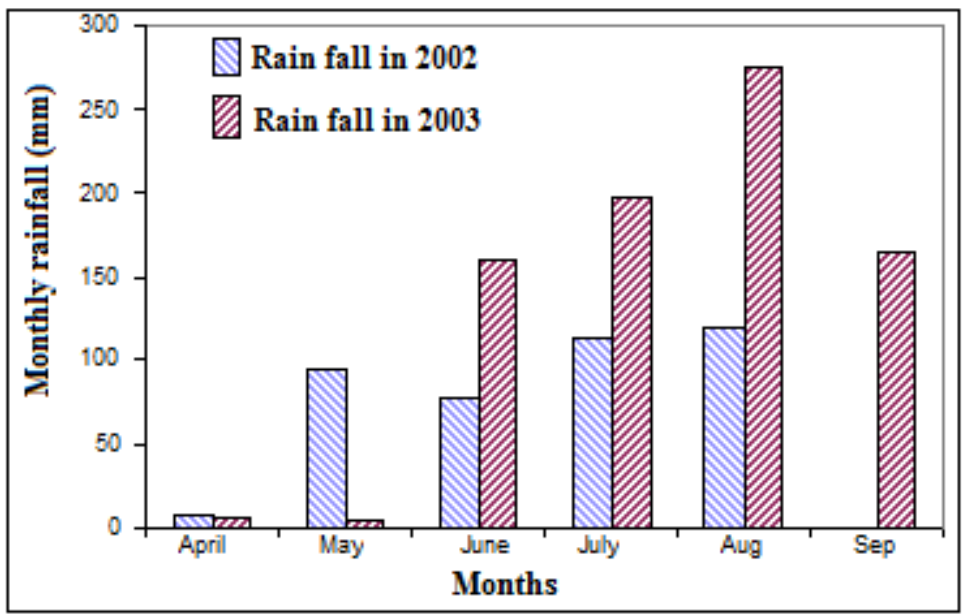

Figure 2.Monthly rainfall at the study site of Abergelle in 2002 and 2003 crop seasons.

\section{DISCUSSION}

\subsection{Rainfall Distribution and Amount:Implication on Sorghum Production}

The monthly rainfall for the crop seasons of 2002 and 2003 is shown in figure 2. The amount of rainfall was lower in 2002as compared to2003crop season. The monthly total rainfall in July and 
August 2002 was almost similar, but rainfall recorded in August 2003 was more than that of July 2003. Rainfall amount in September was none to very little in the crop seasons of 2002 and 2003, respectively. This indicated that the rainfall stopped before the vegetative stage of the sorghum crop. The rainfall in April 2002 was almost the same as that of April 2003 but more rainfall was recorded in May 2002 than May 2003. These matters the planting date of sorghum, especially for early planting varieties. In general, in such situation, the presence of appropriate soil and water management practices such as bunds at the desired spacing is important to enhance soil moisture harvesting. In addition, application of in situ moisture retention measures such as tied-ridging can support for crops by improving both soil water and nutrient uptake to skip the shortage of soil water at the germination and vegetative stage of the crop. Soil water shortage at these crop stages are the frequently noted problems in the semi-arid areas of Ethiopia such as the study area.

\subsection{Effect of Tillage and Fertilizer Practices on Sorghum Production}

This study showed that the extent of sorghum productivity can be constrained by soil water, and nitrogen $(\mathrm{N})$ and phosphorus $(\mathrm{P})$ availability in semiarid areas. In spite of this fact, farmers in semiarid areas are not practicing appropriate tillage practices such as tied-ridging that improved soil water and the availability of $\mathrm{N}$ and $\mathrm{P}$ nutrients added as fertilizer to soils. This research played its role in demonstrating at farmers' fields the importance of different tillage and fertilizer treatments in boosting biomass and grain yield by reducing the problems of soil water stress and fertility deficits. Studies reported that soil moisture deficit for crop production in the semi-arid northern Ethiopia is not mainly associated with the amount of rainfall in the crop season but also influenced by type and time of soil and management practices applied (e.g., Gebreyesus Brhane et al., 2006). It can also be due to the temporal rainfall variability, for instance, rainfall is highly concentrated in July and August but stopped in the early of September at vegetative crop stage besides to the rainfall variability between consecutive years (Fig 2). This makes difficult to predict the regular planting time for crops such as sorghum. Even thoughtime of planting was not addressed for a particular variety in this study, for the situation of the semi-arid area appropriate moisture harvesting techniques such as tied-ridging is essential for increasing soil moisture for crop establishment and during grain filling. The beneficial effects of tied-ridging on crop yield can be varied with differences in amount and distribution of rainfall, variety, fertilizer conditions and the time of ridging application. 
The present study demonstrated that the implementation of tillage practices such as tied-ridging contributed for improving crop establishment and grain filling and thereby resulted in higher yield and yield components of sorghum as compared to zero tillage and the traditional ridging (shilshalo) (Tables 2, 3, 4). For example, plant height, panicle length, plant stand count and 1000 seed weight were significantly influenced by the tillage and fertilizer interaction and their separate effects. Tillage practices that retained soil water better from being lost as surface runoff such as TROWAP improved well the crop growth and development parameters. The growth parameters can result in differences in the yield of the sorghum crop varieties. The lowest value of the crop growth parameters were recorded by ZT treatment, which could be associated to the soil moisture problem for the sorghum crop varieties particularly at the establishment and flowering stage. The yield increment due to tied-ridging with fertilizer interaction effect was higher for both sorghum crop varieties as compared to the interaction effect of the other tillage treatments with fertilizer. But the interaction effect of F2 with the tillage practices on the yield and yield components of sorghum was higher than that of F1(Tables $2 \& 3$ ). The implementation time for the tied-ridging can be resulted in a significant influence on the yield and yield components of the sorghum varieties. This is evidenced by the tillage practice which is TROWAP that influenced yield and yield components of both sorghum varieties better than the other tillage practices tested in this research. In general, the increment in grain yield due to the treatments was higher for the variety Chibal as compared to Woitozira. Such differences may arise due to the fact that Chibal is late planted but matured early which requires small amount of soil water at vegetative stages. Such soil water can be captured by the tied-ridging implemented for the different stages of the crop. The stover yield was also higher for Chibal as compared to Woitozira in all the treatments. Stover yield is valued because the stems are used for hatching and fuel, and the leaves and stems are used for cattle feed during the long dry season. The grain is the most valued part of the harvest because it provides a staple food, and the surplus production is marketed.

Generally, the treatment interaction effects of tillage and fertilizer on the Chibal variety showed that the interaction effect of TR0WAP with F1 increased grain yield better as compared to SRP, TR4WAP, SBP and ZT by 10, 19, 20 and 48\%, respectively. Similarly, TR0WAP with F2 increased grain yield as compared to those tillage practices by 7, 23, 28 and 45\%, respectively, for Chibal variety. The performance of ZT was improved by using fertilizer. Moreover, the (C) CNCS, Mekelle University 
interaction effect of tillage with F1 on the Woitozira variety indicated that TR0WAP increased grain yield better as compared to TR4WAP, SRP, SBP and ZT by 4, 21, 25 and 48\%, respectively. The TROWAP interaction with F2 increased grain yield of Woitozira over the TR4WAP, SRP, ZT and SBP by 7, 12, 25 and 27\%, respectively. Such results indicate that highest grain yield increments were related to interaction effect of the tied-ridging treatment with fertilizer for both varieties. But the increased in percentage of the grain yield was lower for Woitozira than Chibal variety. The results of this study showed consistency with findings in Gebreyesus Brhane et al. (2006); Gebreyesus Brhane Tesfahunegn and Wortmann (2008); Tewodros Mesfin et al. (2009, 2010) who suggested the importance of tied-ridging and fertilizer integration for increasing crop yield in semi-arid areas. However, these previous studies do not assess about ZT which is considered the important tillage method in other areas of the world. The conditions of the present research also match the criteria for likely yield response to tiedridging as identified by Jones and Clark (1987), i.e., the crop was an annual, there were early rain events to generate runoff and there was limited growing season precipitation. The important point of the present result is that the selection of appropriate crop variety is crucial in order to get the best benefits from tillage practices such as tied-ridging and fertilizer application.

The effects of soil water deficit during the grain-filling period are reflected by the small grain size (seed weight) and low grain yield as observed on zero tillage (ZT) and SBP. This may be due to the low infiltration rate of the soil because infiltration time is too short for soils treated by ZT. In such conditions, crop can be exposed to moisture stress especially at establishment and grain-filling stage. It can be concluded that ZT in the study area might not be appropriate tillage system without pre-soil management that improves the infiltration and water holding capacity of the soil. Zero tillage (ZT) will have a positive environmental effect globally by sequestering carbon (Desjardins et al., 2002; Aune et al., 2006). It is also reported that ZT sequesters carbon because there is a lower decomposition rate of soil organic matter and this is associated more with recycling of organic matter (Desjardins et al., 2002; Aune et al., 2006). For this reason, the effect of ZT on soil and thereby on crop yield should be assessed for longer periods in the northern Ethiopia conditions.

The results of this study confirmed and summarized that the effectiveness of tied-ridging tillage combined with fertilizer resulted in a general higher yield for the Chibal variety as compared to their effect on Woitozira sorghum variety. This study also indicated that soil moisture without 
soil fertility and fertilizer without soil moisture is less effective for crop production increment in the semiarid areas. Therefore, application of suitable soil and water management practices such as tied-ridging tillage should be integrated with fertilizer to improve the soil water and soil fertility at the same time for production enhancement in the study area conditions.

\section{CONCLUSION}

This study demonstrated that the application of appropriate tillage and fertilizer practices are important to increase crop production in the semiarid areas of Ethiopia. Tied-ridging tillage made at planting (TR0WAP) without fertilizer(F1) increased sorghum yield of Woitozira (early planted)(48\%) and Chibal (late planted)(49\%) higher than the zero tillage (ZT).For the interaction effect of TR0WAP with fertilizer (F2), grain yield increased by $27 \%$ for the early planted variety as compared to shilshalo, and about $45 \%$ for the late planted variety as compared to ZT, indicating that there is synergetic effect of soil moisture and soil nutrients on productivity. The interaction effect of tillage with fertilizer significantly improved the yield of early and late planted sorghum varieties, though its effect is more magnified on the late planted (Chibal) variety across the two years. In this study, the worst average yield was recorded with zero tillage treatment which has not yet been practiced by most farmers in the area, followed by the traditional ridging (shilshalo). But interaction effect of tillage practices with fertilizer improved the sorghum yields better even in ZT. Tied-ridging at planting (TROWAP) followed by TR4WAP with fertilizer are suggested as the appropriate practices because in the presence of such practices yield and yield components of the two sorghum varieties are improved in the Abergelle area, northern Ethiopia.Generally, the adoption of tied-ridging should be worthwhile regardless of the amount of fertilizer applied for semi-arid areas as compared to the other tillage practices evaluated in this study.

\section{ACKNOWLEDGEMENT}

The author gratefully acknowledge for the participant farmers during the research and Mr. Teka Solomon for his support in data collection and field monitoring during the execution of the research. This research was conducted with the support provided by the Tigray Agricultural Research Institute of Mekelle Research Center and the U.S. Agency for International Development, under the terms of grant no. LAG-G-00-96-900009-00 to the International 
Sorghum and Millet Collaborative Research Support Program (INTSORMIL). The author is also grateful to the anonymous reviewers for their comments, suggestions and corrections.

\section{REFERENCES}

Araya Alemie \& Stroosnijder, L. 2010. Effects of tied ridges and mulch on barley (Hordeum vulgare) rainwater use efficiency and production in northern Ethiopia. Agric.Water Manage., 97: 841-847.

Aune, J.B., Rahel Asrat., Dereje Assefa Teklehaimanot \& Balesh Tulema Bune. 2006. Zero tillage or reduced tillage: The key to intensification of the crop-livestock system in Ethiopia, 309-318pp.

http://www.ifpri.org/sites/default/files/pubs/pubs/books/oc53/oc53ch12.pdf. Accessed 22 Aug 2011.

Benti, T. 1993. The need and objective of the first national maize workshop. In: T. Benti and J. Ranson (eds.), Proceedings of the first national maize workshop of Ethiopia. 5-7 May 1992, IAR/CIMMYT, Addis Abeba, Ethiopia. 1-5pp.

Breman, H., Groot, J.J.R\& Van Keulen, H.2001. Resource limitations in Sahelian agriculture. Global Environmental Changes, 11:59-68.

Central Statistics Authority (CSA). 2000. Agricultural sample survey 1999/2000. Report on area and production for major crops (private peasant holdings, main season). Statistical Bulletin No. 227. Addis Ababa, Ethiopia.

Davidson, O., Halsnaes, K., Huq, S., Kok, M., Metz, B., Sokona, Y \& Verhagen, J. 2003. The development and climate nexus: the case of Sub-Sarahan Africa. Climate Policy, 3:97-113.

Desjardins, R.L, Smith, W., Grant, B., Campbell, C., Janzen, H \& Riznek, R. 2002. Management strategies to sequester carbon in agricultural soils and to mitigate greenhouse gas emissions. Presented at the international workshop on reducing vulnerability of agriculture and forestry to climate variability and climate change. Ljubljanu, Slovenia, Oct. 7-9, 2002.

Freed, R. 1994. MSTATC program [Online]. Available at http://www.msu.edu/ freed/disks.htm (Accessed 28 Feb 2005).

Gebreyesus Brhane, Wortmann, C.S., Martha Mamo, Heluf Gebrekidan \& Amare Belay.2006. Micro-basin tillage for grain sorghum production in semiarid areas of northern Ethiopia. Agronomy Journal, 98:124-128. 
Gebreyesus Brhane Tesfahunegn \& Wortmann, C.S. 2008. Tie-Ridge Tillage for High Altitude PulseProduction in Northern Ethiopia. Agronomy Journal, 100:447-453.

GirmayG/Samuel, Singh, B.R., Nyssen, J \& Borrosen, T. 2009. Runoff and sediment -associated nutrient losses under different land uses in Tigray, northern Ethiopia. J.Hydrol., 376:7080.

Holden, S.T \& Bekele Shiferaw. 2002. Poverty and Land Degradation: Peasants' Willingness to Pay to Sustain Land Productivity. In: C.B. Barrett, F.M. Place and A.A. Aboud (eds.), The Adoption of Natural Resource Management Practices: Improving Sustainable Agricultural Production in Sub-Saharan Africa.CABI Publishing, NewYork, 91-102pp.

Jones,O.R \& Clark, R.N. 1987. Effects of furrow dikes on water conservation and dryland crop yields. Soil Sci. Soc.Am.J., 51:1307-1314.

Mando, A. 1997. The effect of mulch on the water balance of Sahelian crusted-soils. SoilTechnology, 11:121-138.

Morin, J.1993. Soil crusting and sealing in West Africa and possible approaches to improved management. In: FAO (ed.) Soil tillage in Africa: needs and challenges, FAO Soils Bulletin, 69: 95-128.

Pendke, M.S., Lomte, Mitiku Haile \& Gitte, A.U. 2004. Effect of soil and water conservation practices on runoff, soil loss and yield of pigenpea. Journal of Maharashtra Agricultural University, 29:319-321.

Sanchez, P.A., Shepherd, K.D., Soule, J.M., Frank, M.P., Buresh, J.R., Izac, N.A \& Woomer, P. 1997. Soil fertility replenishment in Africa: an investment in natural resource capital. In: R.J. Buresh, P.A. Sanchez and P.A. Calhoun (eds.), Replenishing soil fertility in Africa, Soil Sci. Soc.Am.J., Special Pub.No.51, Madison, 1-46pp.

Sonneveld, B.G.J.S. 2002. Land under pressure: The impact of water erosion on food production in Ethiopia. PhD Thesis, Shaker Publishing, The Netherlands.

Stroosnijder, L \& Van Rheenen, T. 2001. Agro-sylvo-pastoral land use in Sahelian villages. (Advance in GeoEcology 33) Catena Verlag GMBH, Reiskirchen, 408p.

Tewodros Mesfin, Gebreyesus Brhane Tesfahunegn, Wortmann, C.S., Nikus, O \& Mamo, M. 2009. Tied-ridging and fertilizer use for sorghum production in semi-arid Ethiopia. Nutr. Cycl. Agroecosys., 85:87-94. 
Tewodros Mesfin, Gebreyesus Brhane Tesfahunegn, Wortmann, C.S., Martha Mamo \& Nikus, O. 2010. Skip-Row Planting and Tie-Ridging for Sorghum Production in Semiarid Areas of Ethiopia. Agronomy Journal, 102:745-750.

Wortmann, C.S \& Ssali, H. 2001.Integrated nutrient management for resource poor farming systems. A case study of adaptive research and technology dissemination in Uganda. American Journal of Alternative Agriculture, 16:161-167.

Wortmann, C.S., Martha Mamo,Girma Abebe, Kaizzi, K., Mburu, C., Letayo, E \& Xerinda, S.2006. An atlas of sorghum production in eastern Africa. http://intsormil.org. Accessed 15 June 2010.

Zougmoré, R., Gnankambary, Z., Guillobez, S \& Stroosnijder, L. 2002. Effect of stone rows on soil chemical characteristics under continuous sorghum cropping in semiarid Burkina Faso. Soil Till. Res., 66:47-53. 